\title{
GMR
}

\section{Expression of the stem cell factor in fibroblasts, endothelial cells, and macrophages in periapical tissues in human chronic periapical diseases}

\author{
S.Q. Shen*, R. Wang* and S.G. Huang \\ Faculty of Dentistry, School of Medicine, Jinan University, Guangzhou, China \\ *These authors contributed equally to this study. \\ Corresponding author: S.G. Huang \\ E-mail: hsg2016a@163.com
}

Genet. Mol. Res. 16 (1): gmr16019394

Received September 29, 2016

Accepted January 19, 2017

Published March 8, 2017

DOI http://dx.doi.org/10.4238/gmr16019394

Copyright (C) 2017 The Authors. This is an open-access article distributed under the terms of the Creative Commons Attribution ShareAlike (CC BY-SA) 4.0 License.

\begin{abstract}
Stem cell factor (SCF), an important stem cell cytokine, has multiple functions. Fibroblasts (FBs), mature mast cells, endothelial cells (ECs), and eosinophil granulocytes can produce SCF in the inflammatory process. Therefore, we aimed to observe SCF expression in FBs, ECs, and macrophages (MPs) in periapical tissues in human chronic periapical disease and investigate the effects of cells expressing SCF in pathogenesis of the disease. Healthy $(\mathrm{N}=20)$, periapical cyst $(\mathrm{N}=15)$, and periapical granuloma $(\mathrm{N}=15)$ tissues were fixed in $10 \%$ formalin for $48 \mathrm{~h}$, embedded in paraffin, and stained with hematoxylin and eosin to observe histological changes. SCF expression was observed in FBs, ECs, and MPs in periapical tissues by double immunofluorescence. CD334, CD31, and CD14 are specific markers of FBs, ECs, and MPs, respectively. Results showed that densities of CD334-SCF double-positive FBs, CD31-SCF double-positive ECs, and CD14-SCF double-positive MPs were significantly increased in periapical tissue groups $(\mathrm{P}<0.01)$. There were no significant differences in CD334-SCF double-positive FB and CD31-SCF double-positive $\mathrm{EC}$ levels between the two periapical tissue groups $(\mathrm{P}>0.05)$. CD14-
\end{abstract}

Genetics and Molecular Research 16 (1): gmr16019394 
SCF double-positive MP density was considerably higher in periapical granulomas than in cysts $(\mathrm{P}<0.01)$. FB, EC, and MP levels were significantly high and densities of CD334-SCF double-positive FBs, CD31-SCF double-positive ECs, and CD14-SCF double-positive MPs improved considerably in chronic periapical tissues, suggesting that the cells might be related to occurrence, development, and pathogenesis of chronic periapical disease.

Key words: Chronic periapical disease; Stem cell factor; Fibroblasts; Endothelial cells; Macrophages

\section{INTRODUCTION}

Stem cell factor (SCF), also known as steel factor or c-Kit ligand, has two protein forms, namely, membrane-bound stem cell factor and soluble stem cell factor, which mainly act on proliferation, migration, survival, and differentiation of hematopoietic progenitor cells, melanocytes, and generative cells (Lennartsson and Rönnstrand, 2012). In the inflammatory process, fibroblasts (FBs) and endothelial cells (ECs) can produce SCF. Since mature mast cells (MCs) and eosinophil granulocytes have tropism for SCF, they can adhere to fibronectin or ECs and exhibit degranulation (Pradier et al., 2014). In this study, double immunofluorescence (DIF) was used to observe the expression of CD334-SCF double-positive FBs, CD31-SCF double-positive ECs, and CD14-SCF double-positive MPs in human chronic periapical disease tissues and investigate their involvement in the disease mechanism.

\section{MATERIAL AND METHODS}

\section{Subjects}

Study subjects were recruited from the Affiliated Stomatological Hospital of Jinan University between July 2013 to July 2015. The patient group consisted of 15 patients with periapical cysts and 15 patients with periapical granuloma (ages ranging from 24 to 65 years). The 20 control samples were obtained from healthy premolar teeth extracted from individuals (ages ranging from 15 to 23 years) for orthodontic purposes. Pregnant women or individuals with systemic diseases were excluded. Individuals who were not on antibiotics three months prior to study commencement were selected. The study met specified standards of the Institutional Review Board (IRB) and received its approval. In addition, informed written consent was obtained from all study participants.

\section{Groups and materials}

Samples were divided into the three groups: the control, periapical granuloma, and radical cyst groups. The control group consisted of 20 samples obtained from healthy premolar teeth extracted for orthodontic purposes. The periapical granuloma group consisted of 15 samples showing round or oval transmission shadows with low density in the apical area (diameter $\leq 1 \mathrm{~cm}$ ) detected by X-rays imaging. Lesion tissues were pathologically examined to be granulated, accompanied with capillary proliferation and high inflammatory

Genetics and Molecular Research 16 (1): gmr16019394 
cell infiltration and without non-keratinized stratified squamous epithelium. The radicular cyst group consisted of 15 samples showing round or oval transmission shadows with lowdensity in the apical area (diameter $\leq 1 \mathrm{~cm}$ ) and obvious ray resistance in their edge detected by X-ray. Lesion tissues were pathologically examined to contain numerous collagen fibrils, which were cysts or tissues covered with fully or partly non-keratinized stratified squamous epithelium.

\section{Methods}

\section{Collection and treatment of tissue samples}

The periapical granuloma and radicular cyst samples were obtained from lesion tissues during apicetomy. Control group samples were obtained by using a sterile blade and scraping the parodontium of healthy premolar teeth extracted because of orthodontic purposes. The periodontal tissues were fixed in $10 \%$ formalin for over $48 \mathrm{~h}$, dehydrated, embedded, sectioned into 5- $\mu \mathrm{m}$ continuous slices, and then stained with hematoxylin and eosin (HE) for histopathology analysis by microscopy.

\section{Detection of CD334-SCF in FBs, CD31-SCF in ECs, and CD14-SCF in MPs by DIF}

The first antibodies used in this study with a dilution rate of 1:100 were as follows: anti-SCF (Santa Cruz Biotechnology, Santa Cruz, CA, USA), CD14 antibody (Santa Cruz Biotechnology), CD31 antibody (Santa Cruz Biotechnology), and CD334 antibody (Santa Cruz Biotechnology). The secondary antibodies used in this study with a dilution rate of 1:200 were as follows: goat-anti-mouse $\operatorname{IgG}(\mathrm{H}+\mathrm{L})$ Alex Flour $555^{\circledR}$ (Cell Signaling Technology, Danvers, MA, USA) and goat-anti-rabbit IgG $(\mathrm{H}+\mathrm{L})$ Alex Flour $488^{\circledR}$ (Cell Signaling Technology). Tissue slices were dewaxed, repaired with saline sodium citrate buffer, blocked with goat serum, incubated using the first antibody, and washed with phosphatebuffered saline thrice for $5 \mathrm{~min}$. The slices were then incubated with the secondary antibody in the dark, stained with 4',6-diamidino-2-phenylindole, and immediately observed under fluorescence microscope. CD334+, CD31+, and CD14+ showed green light signals, while $\mathrm{SCF}+$ showed a red light signal, located in the cell membrane and/or cytoplasm. The light was orange when red and green light signals merged in the same field. Slices were blindly observed under a fluorescence microscope by two pathologists according to the counting method reported by Batista et al. (2005), gaining double-positive cells per square (cells/ $\mathrm{mm}^{2}$ ). The average value recorded by this method corresponded to the average density of CD334+SCF double-positive FBs, CD14+SCF double-positive MPs, and CD31+SCF double-positive ECs in slices.

\section{Statistical analysis}

Data are reported as means \pm SD and were analyzed by SPSS 13.0 software. The Kruskal-Wallis test was used to compare the average densities of CD334+SCF double-positive FBs, CD14+SCF double-positive MPs, and CD31+SCF double-positive ECs. The Nemenyi test was conducted to compare each cell type independently among the patient and control groups. $\mathrm{P}<0.05$ was considered statistically significant.

Genetics and Molecular Research 16 (1): gmr16019394 


\section{RESULTS}

\section{Histological analysis}

No obvious infiltration of inflammatory cells was observed in the control group (Figure 1A). However, there was excessive infiltration of inflammatory cells such as neutrophilic granulocytes, lymphocytes, and MPs, and capillary proliferation (Figure 1B) in the periapical granuloma group. In the radicular cyst group, we observed intercellular edema and excessive infiltration of inflammatory cells (mainly neutrophilic granulocytes) in the epithelial layer (Figure 1C) and collagen fibrils without infiltration of inflammatory cells in the fibrous tissue layer (Figure 1D).
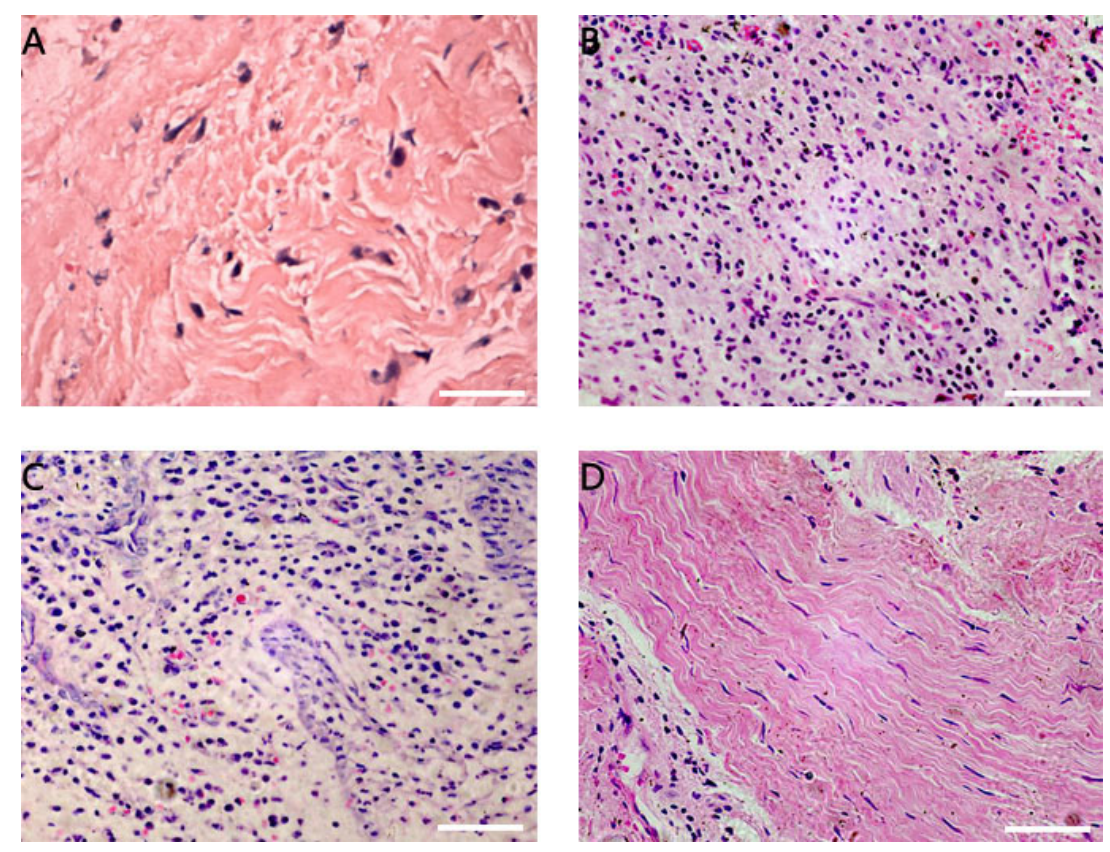

Figure 1. Results from histological analysis. A. Healthy control group; B. periapical granulomas group; C. radicular cysts group; D. fibrous tissue layer.

\section{DIF results}

SCF were found to be expressed in FBs, ECs, and MPs in each group. A few CD334SCF double-positive FBs, CD31-SCF double-positive ECs, and CD14-SCF double-positive MPs were observed to be scattered in the control group (Figure 2, Figure 3, and Figure 4). In the periapical granuloma group, CD334-SCF double-positive FBs, CD31-SCF doublepositive ECs, CD14-SCF double-positive MPs, and erythrocytes were dramatically increased (Figure 5, Figure 6, and Figure 7). Besides, in the radicular cyst group, CD334-SCF doublepositive FBs, CD31-SCF double-positive ECs, CD14-SCF double-positive MPs, and mature erythrocytes were increased (Figure 8, Figure 9, and Figure 10). 

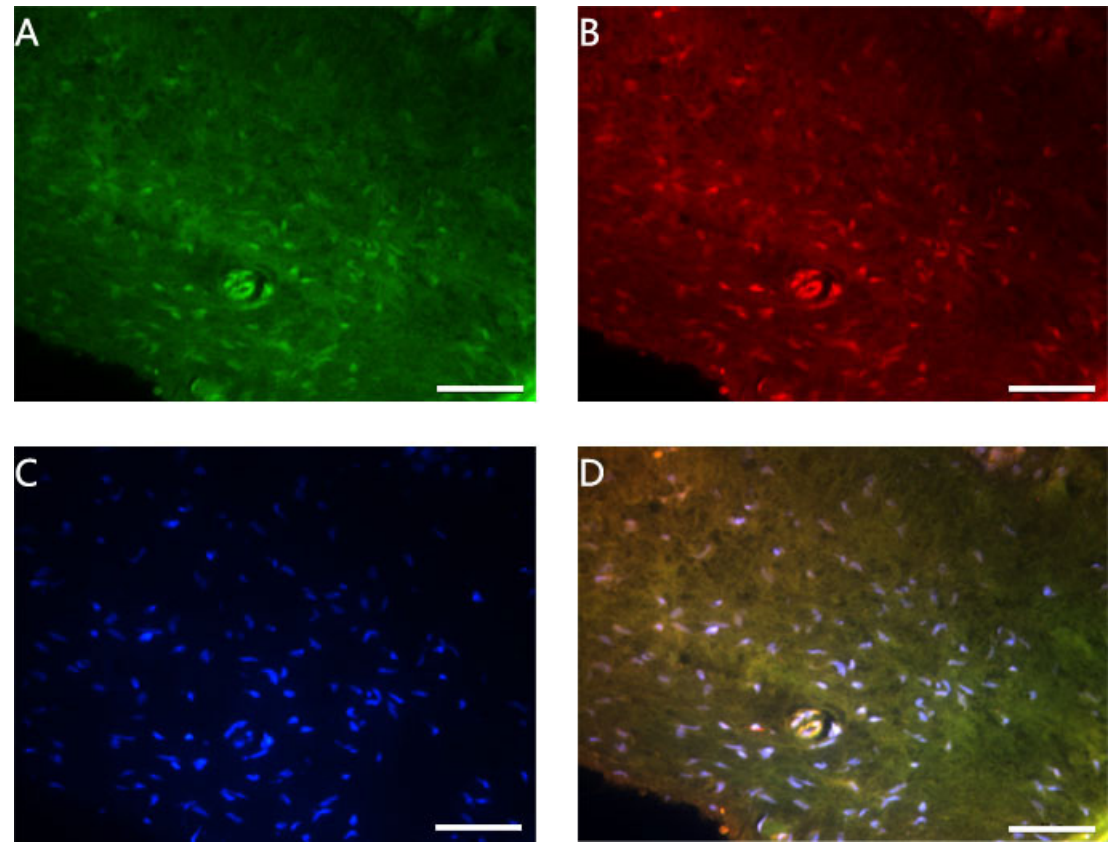

Figure 2. Double immunofluorescence results of fibroblasts in the healthy control group. A. $\mathrm{CD}_{334^{+}} ; \mathbf{B} . \mathrm{SCF}^{+} ; \mathbf{C}$. $\mathrm{DAPI}^{+}$; D. Merged (scale bars $=50 \mu \mathrm{m}, 400 \mathrm{X}$ ).
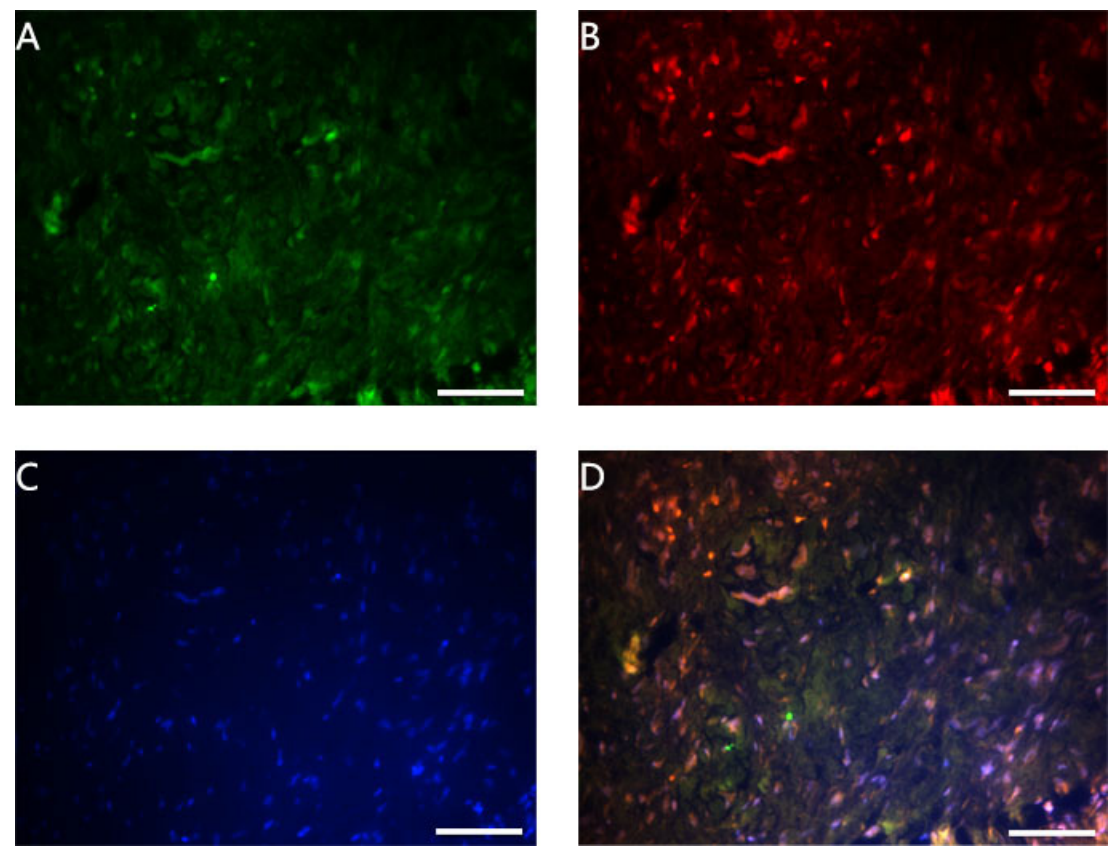

Figure 3. Double immunofluorescence results of endothelial cells in the healthy control group. A. CD31 $1^{+}$; $\mathbf{B} . \mathrm{SCF}^{+}$; C. $\mathrm{DAPI}^{+} ;$D. Merged (scale bars $=50 \mu \mathrm{m}, 400 \mathrm{X}$ ).

Genetics and Molecular Research 16 (1): gmr16019394 

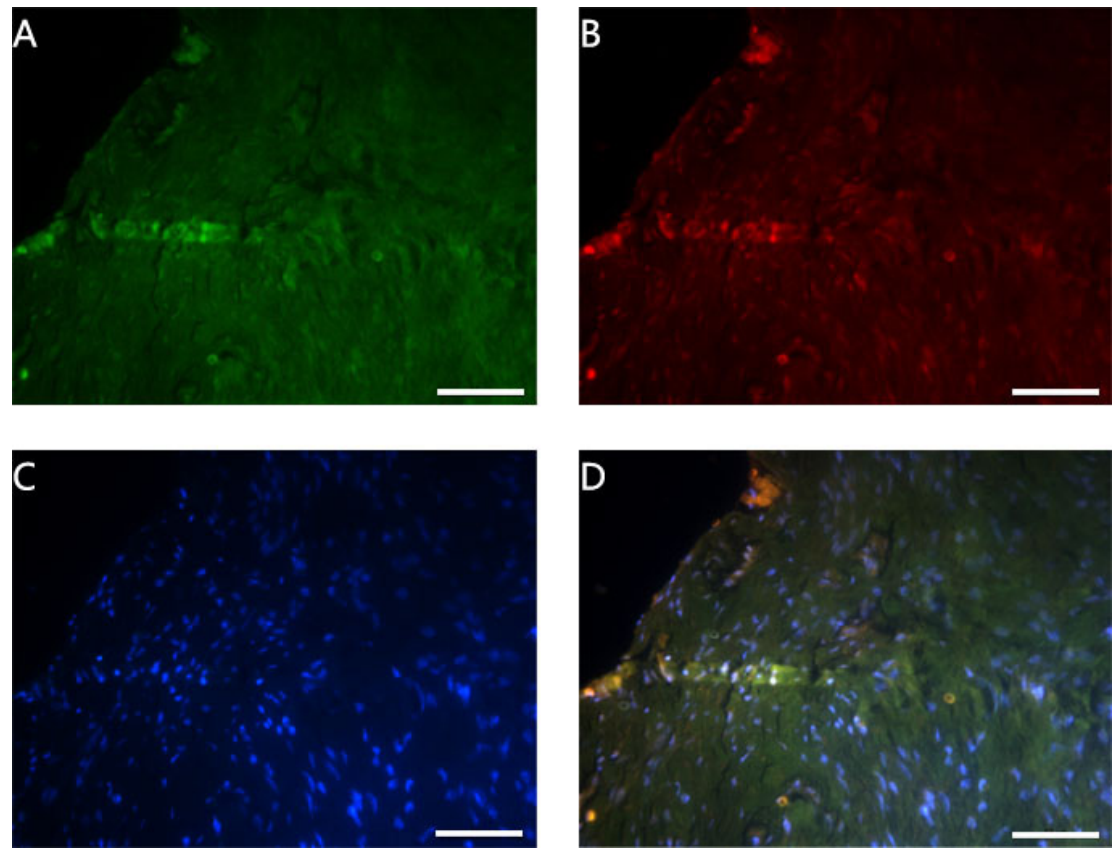

Figure 4. Double immunofluorescence results of macrophages in the healthy control group. A. $\mathrm{CD}^{+}$; $\mathbf{B} . \mathrm{SCF}^{+}$; C. DAPI $^{+}$; D. Merged (scale bars $=50 \mu \mathrm{m}, 400 \mathrm{X}$ ).
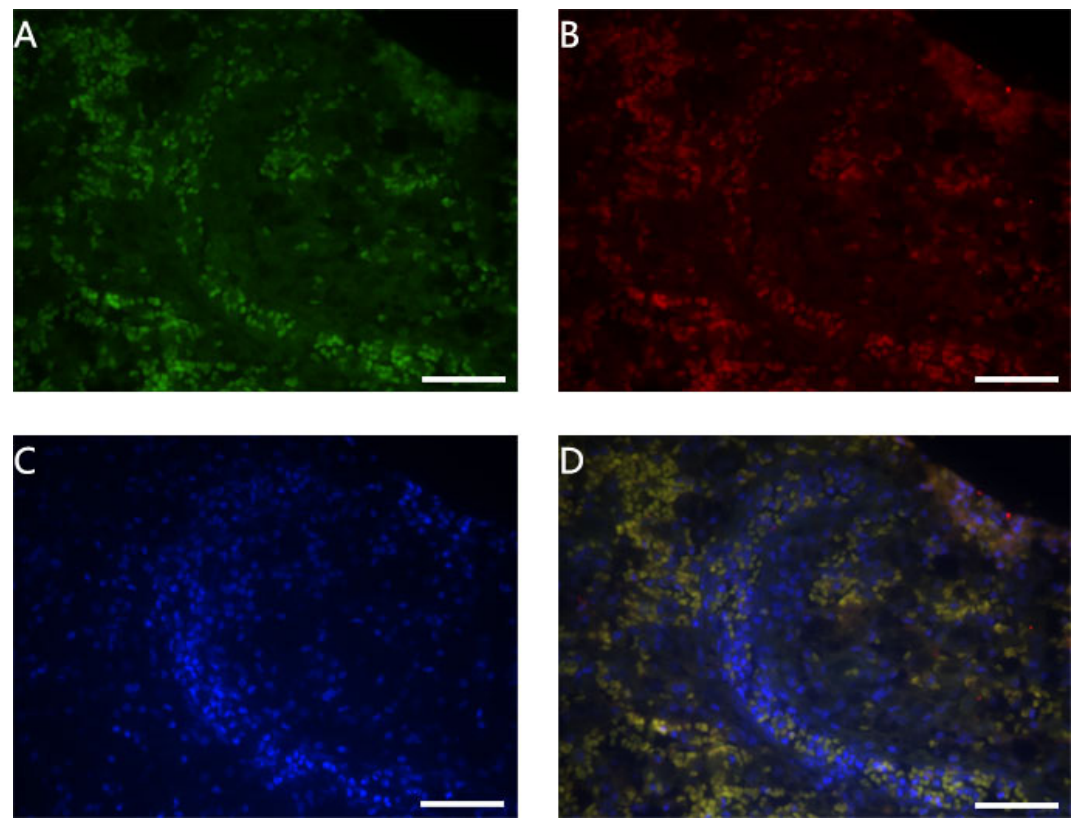

Figure 5. Double immunofluorescence results of fibroblasts in the periapical granuloma group. A. CD334 ; B. $\mathrm{SCF}^{+} ;$C. $\mathrm{DAPI}^{+} ;$D. Merged (scale bars $\left.=50 \mu \mathrm{m}, 400 \mathrm{X}\right)$.

Genetics and Molecular Research 16 (1): gmr16019394 

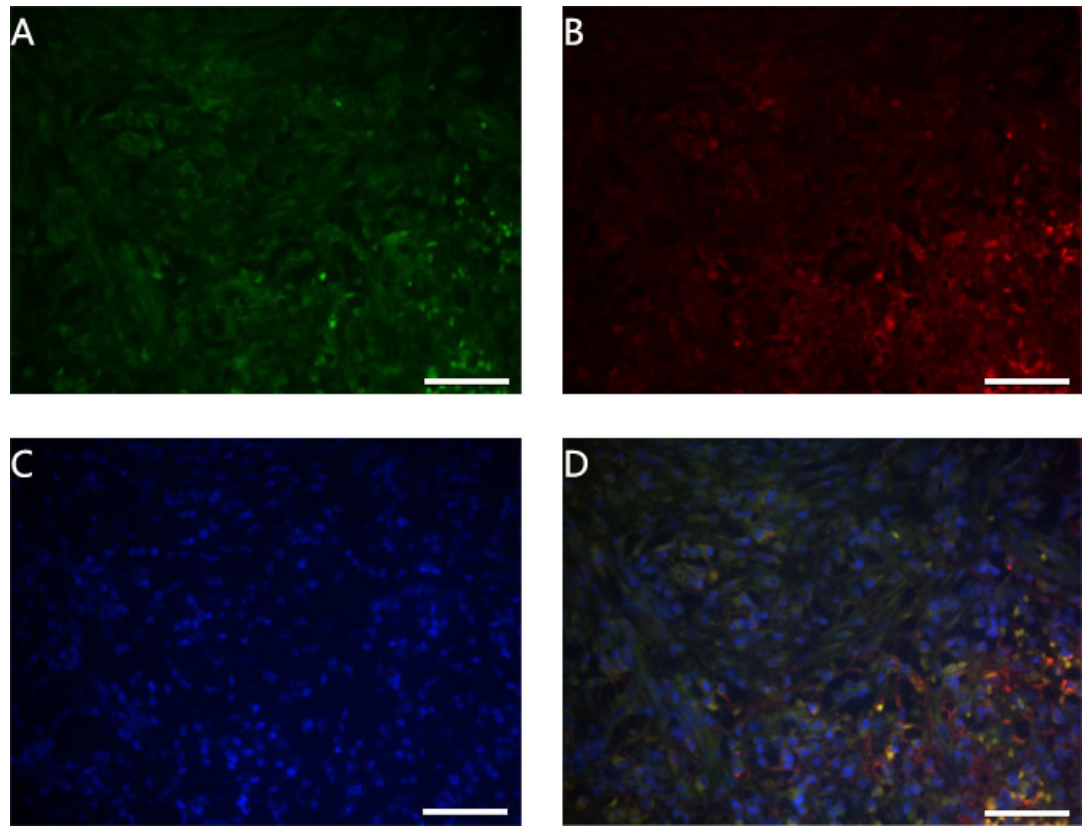

Figure 6. Double immunofluorescence results of endothelial cells in the periapical granuloma group. A. CD $31^{+}$; B. $\mathrm{SCF}^{+}$; C. DAPI $;$D. Merged (scale bars $=50 \mu \mathrm{m}, 400 \mathrm{X}$ ).
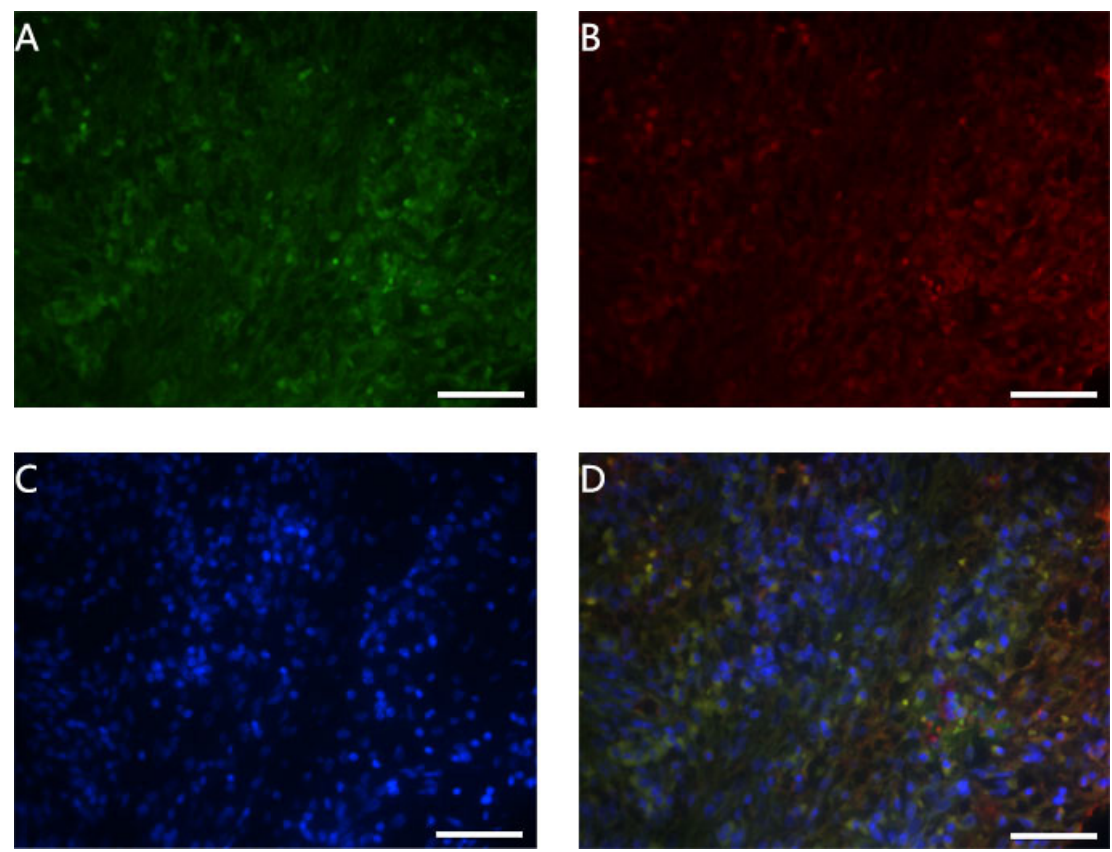

Figure 7. Double immunofluorescence results of macrophages in the periapical granuloma group. A. CD14 B. $\mathrm{SCF}^{+}$; C. DAPI ${ }^{+}$; D. Merged (scale bars $=50 \mu \mathrm{m}, 400 \mathrm{X}$ ).

Genetics and Molecular Research 16 (1): gmr16019394 

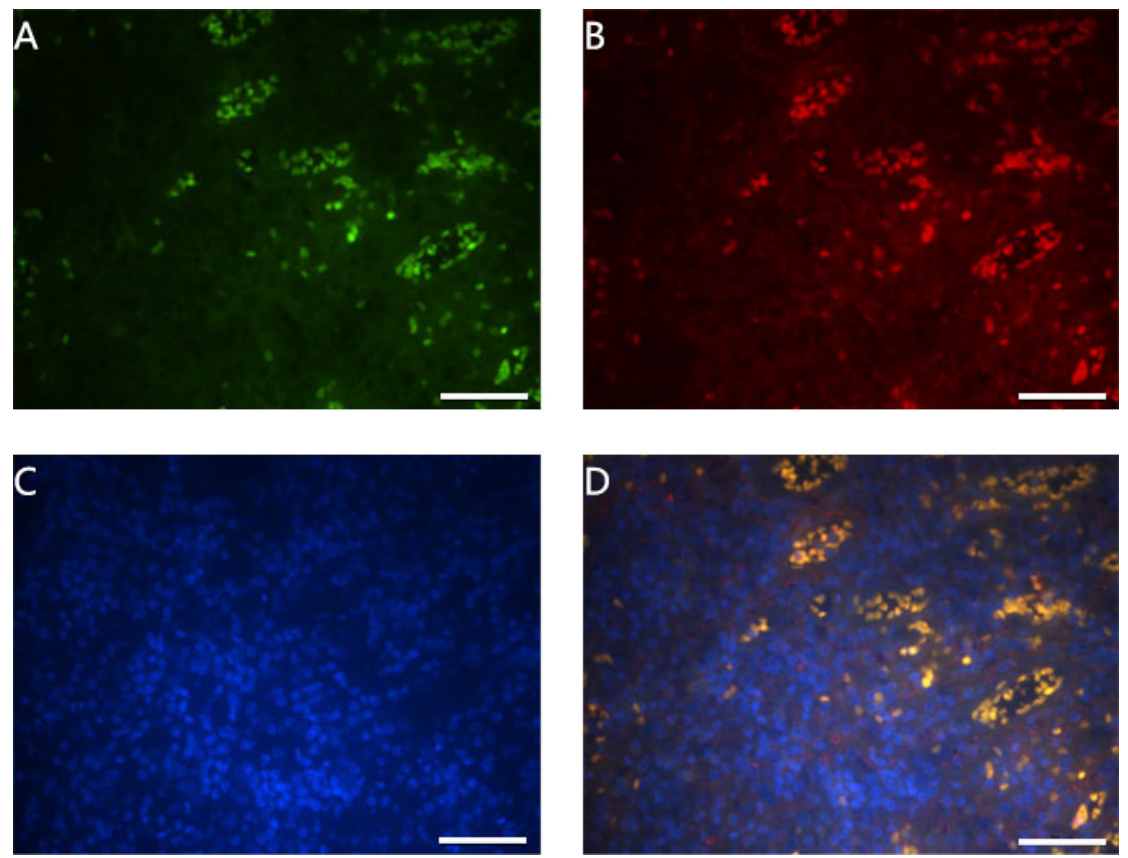

Figure 8. Double immunofluorescence results of fibroblasts in the radicular cyst group. A. $\mathrm{CD}_{334^{+}}$; B. $\mathrm{SCF}^{+}$; C. DAPI ${ }^{+}$D. Merged (scale bars $=50 \mu \mathrm{m}, 400 \mathrm{X}$ ).
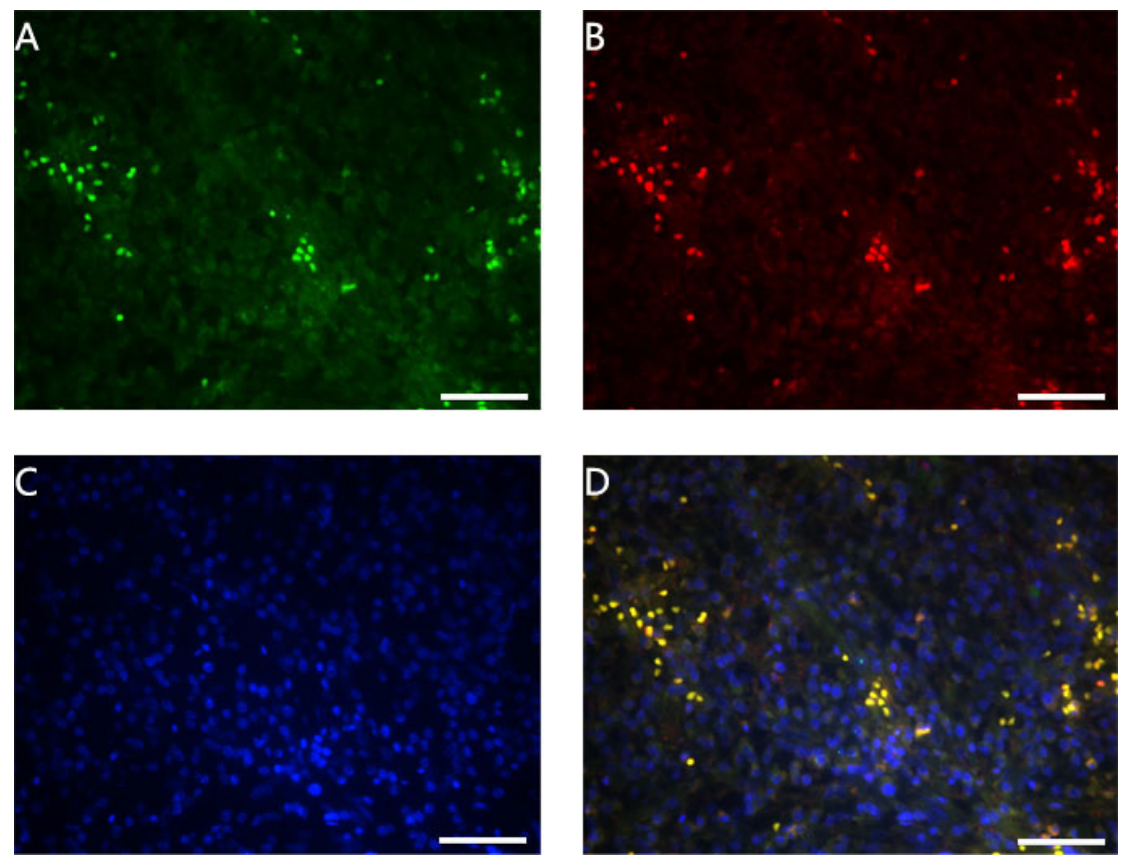

Figure 9. Double immunofluorescence results of endothelial cells in the radicular cyst group. A. CD31 ${ }^{+}$; B. $\mathrm{SCF}^{+}$; C. $\mathrm{DAPI}^{+} ;$D. Merged (scale bars $\left.=50 \mu \mathrm{m}, 400 \mathrm{X}\right)$.

Genetics and Molecular Research 16 (1): gmr16019394 

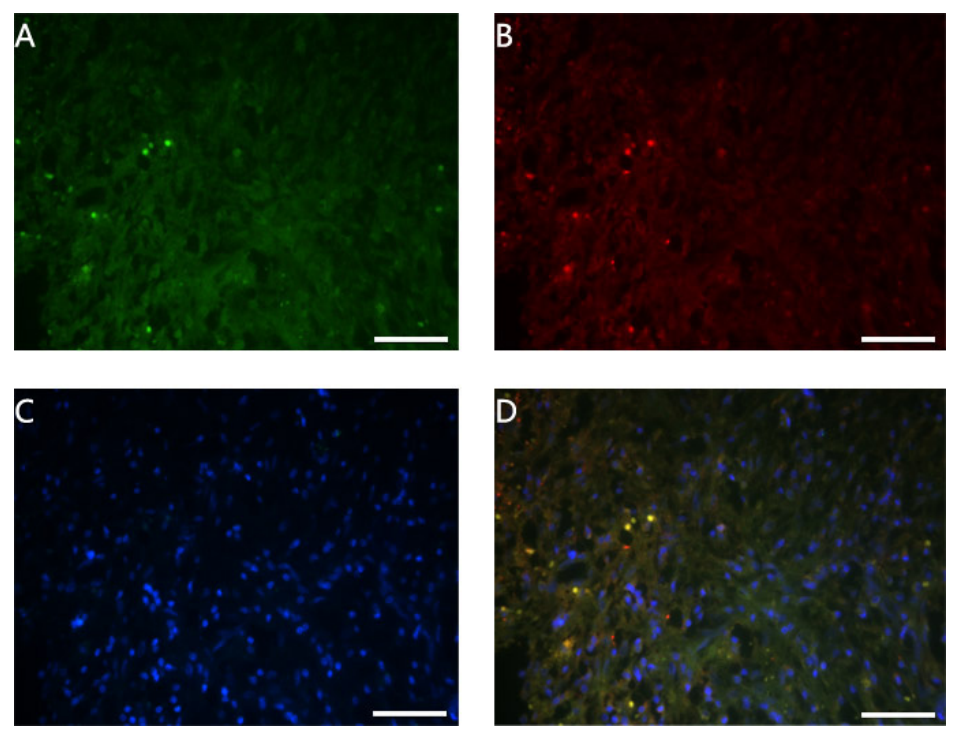

Figure 10. Double immunofluorescence results of macrophages in the radicular cyst group. A. $\mathrm{CD}_{1}^{+} ;$B. SCF S $^{+}$. DAPI $^{+}$; D. Merged (scale bars $\left.=50 \mu \mathrm{m}, 400 \mathrm{X}\right)$.

\section{Density of CD334+SCF double-positive FBs in each group}

As shown in Figure 11, there were significant differences in the density of CD334SCF double-positive FBs between the control group and periapical tissue groups $(\mathrm{P}<0.01)$, while no differences were observed between the periapical granuloma and radicular cyst groups $(\mathrm{P}>0.05)$.

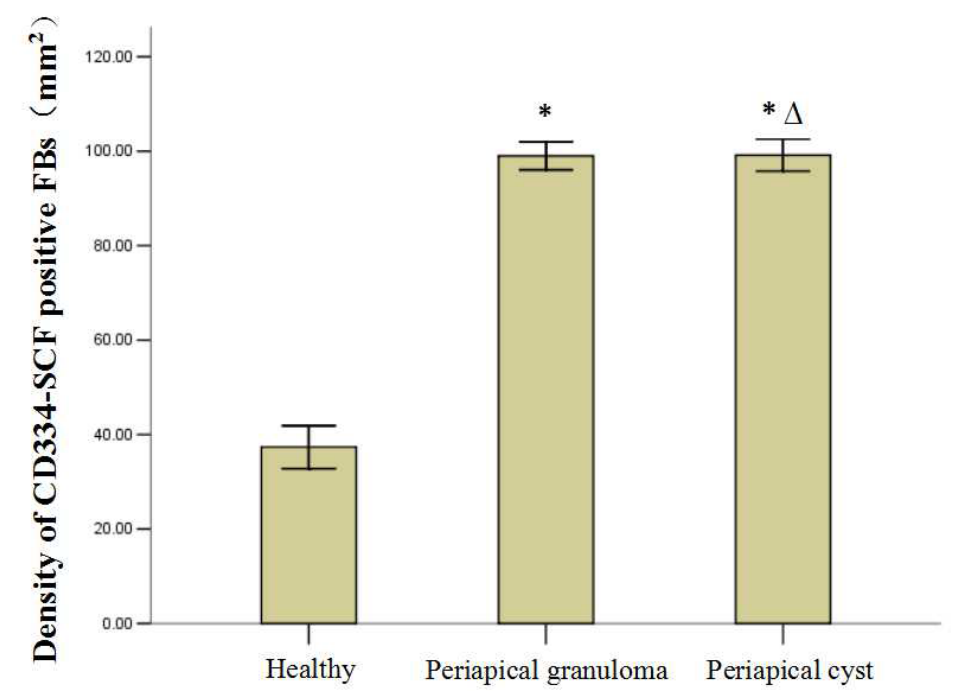

Figure 11. Density of CD334+SCF double-positive fibroblasts in each group. Mean $\pm \mathrm{SD}$. $* \mathrm{P}<0.01$ vs healthy control group; ${ }^{\wedge} \mathrm{P}>0.05$ vs periapical granuloma group. 


\section{Density of CD31+SCF double-positive ECs in each group}

As shown in Figure 12, there were significant differences in the density of CD31-SCF double-positive ECs between the control group and periapical tissue groups $(\mathrm{P}<0.01)$, while no differences were observed between the periapical granuloma and radicular cyst groups $(\mathrm{P}>0.05)$.

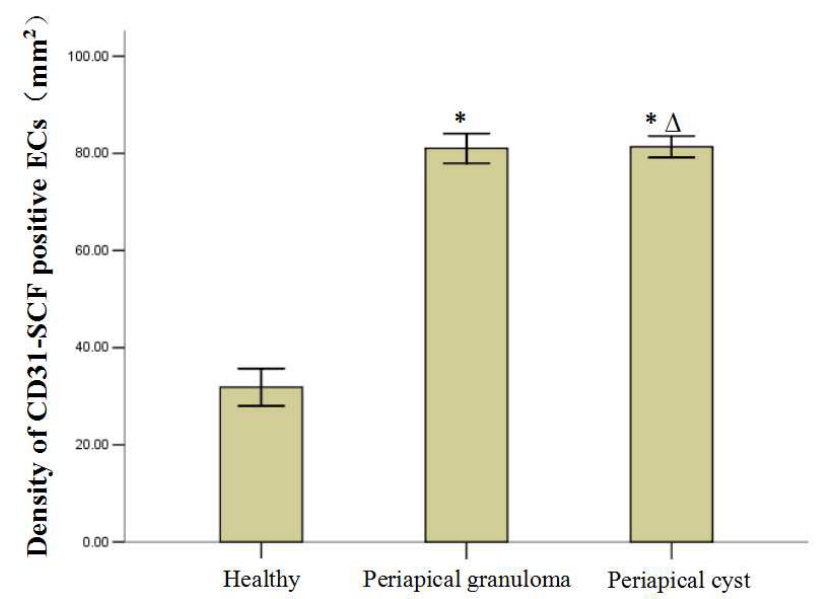

Figure 12. Density of CD $31+\mathrm{SCF}$ double-positive endothelial cells in each group. Mean $\pm \mathrm{SD}$. $* \mathrm{P}<0.01 v s$ healthy control group; ${ }^{\wedge} \mathrm{P}>0.05$ vs periapical granuloma group.

\section{Density of CD14+SCF double-positive MPs in each group}

As shown in Figure 13, there were significant differences in the density of CD31-SCF double-positive ECs between the control group and periapical tissue groups $(\mathrm{P}<0.01)$. The density was considerably higher in the periapical granuloma group than in the radicular cyst group $(\mathrm{P}<0.01)$.

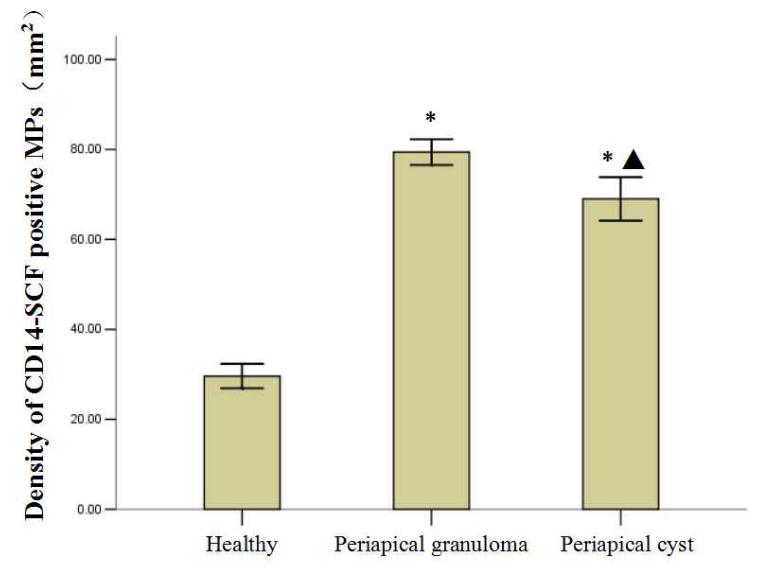

Figure 13. Density of CD14+SCF double-positive macrophages in each group. Mean $\pm \mathrm{SD}$. ${ }^{*} \mathrm{P}<0.01$ vs healthy control group; ${ }^{\Delta} \mathrm{P}<0.01$ vs periapical granuloma group.

Genetics and Molecular Research 16 (1): gmr16019394 


\section{Density of CD334-SCF double-positive FBs, CD31-SCF double-positive ECs, and CD14-SCF double-positive MPs in each group}

The results are shown in Figure 14, and the differences have been described above.
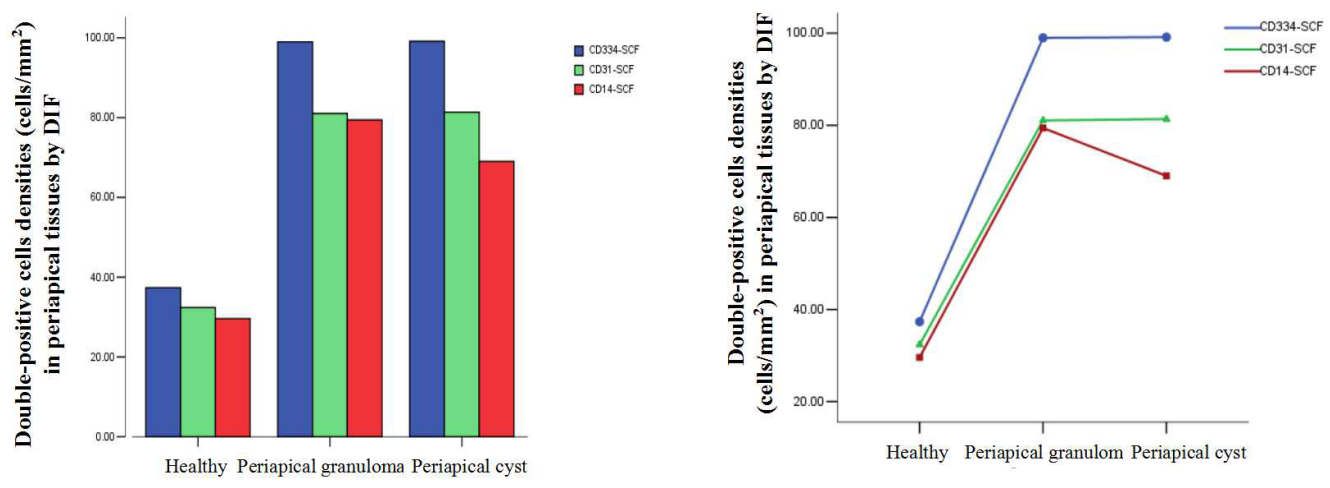

Figure 14. Density of CD334-SCF double-positive fibroblasts, CD31-SCF double-positive endothelial cells, and CD14-SCF double-positive macrophages in each group.

\section{DISCUSSIONS}

Chronic periapical disease is characterized by the inflammation and destruction of periapical tissues. The bacteria and its virulence factor in an infectious root canal enter periapical tissues and stimulate the host inflammatory reaction and immune mechanism by apical foramina, produce various pro-inflammatory cytokines such as tumor necrosis factor $\alpha$ (TNF- $\alpha$ ), interleukin-1 $\beta$ (IL-1 $\beta$ ), and interleukin-6, and directly cause osteoclast formation and bone absorption (Jakovljevic et al., 2015).

In human chronic periapical disease tissues, excessive infiltration of lymphocytes (LYMs), plasmocytes, FBs, MPs, and MCs has been observed with EC swelling and capillary proliferation (Fan and Zhou, 2012). It has been proven that active MPs and LYMs are the cells responsible for periapical tissue inflammation and bone absorption at the early stage of disease (Takeichi et al., 2008). MPs are involved in phagocytosis in the inflammation process and can be promoted by microorganism lipopolysaccharides as well as chemical mediators to produce IL- $1 \beta$ and TNF- $\alpha$, activate osteoclast, and cause periapical bone absorption and destruction (Nair, 2004). IL-1 $\beta$ has the ability to affect T cells and ECs in periapical tissues for an improved local immune reaction, while TNF- $\alpha$ can stimulate FB proliferation and promote local tissue fibrosis (Solanki et al., 2013).

A study reported that ECs play an important role in human chronic periapical disease, and various pro-inflammation cytokines could destroy the close association of ECs, improving endothelial permeability in the inflammatory reaction and immune process (Hama et al., 2008). ECs have also been found to have the ability to regulate inflammation in periapical tissues by controlling the movement of inflammatory cells and increasing blood vessel permeability (Takeichi et al., 2008). 
In the inflammatory process, FBs could proliferate to form fibrotic tissues and encompass lesion areas, forming a type of fibrous coat to restrict the spread of inflammation into deep tissues (Fan and Zhou, 2012). LPS in infected pulp tissues of pulp canal could activate LYMs and FBs producing pro-inflammatory cytokines such as TNF and IL-1 (Chang et al., 2005). Some studies have suggested that FBs could be activated to secret inflammatory cytokines, such as NLRP3 and IL-33, after stimulation of inflammation and participate in infiltration, cell transport, and tissues fibrosis in the tissue repair process (Liu and Liu, 2013; Sipert et al., 2014; Velickovic et al., 2016).

$\mathrm{SCF}$, an important stem cell cytokine with multiple functions, has been extensively studied (Fang et al., 2012). Over-expression of SCF/c-Kit is associated with the inflammatory reaction, proliferation spread, and wound repair (Kalra et al., 2013). Expression of the SCF/cKit receptor and its ligand in epithelial tissues has been found to be associated with neoplastic transformation (Gagari et al., 2006). Therefore, SCF has a close relationship with allergic asthma, liver tissue fibrosis, small cell lung cancers, and so on (Choudhary et al., 2016). Another study reported that the SCF/c-Kit pathway could promote tissue angiogenesis and reconstruction (Kim et al., 2014). In the inflammatory process, FBs and ECs produce SCF, while mature MCs and eosinophil granulocytes express SCF by adhering to fibronectin or ECs and show degranulation (Kim et al., 2014).

Studies have shown that there is excessive infiltration of FBs, ECs, and MPs in periapical tissues of patients with chronic periapical disease. However, the mechanism of SCFpositive FBs, ECs, and MPs in the incidence, development, and progression of the disease has not been elucidated. In the current study, DIF results showed that the densities of CD334SCF double-positive FBs, CD31-SCF double-positive ECs, and CD14-SCF double-positive MPs were all significantly higher in the chronic periapical groups than in the control group. No significant differences were observed in the densities of CD334-SCF double-positive FBs and CD31-SCF double-positive ECs in the periapical granuloma and radicular cyst groups. The density of CD14-SCF double-positive MPs was considerably higher in the periapical granuloma group than in the radicular cyst group. Our study indicated that controlling or regulating the functions of FBs, ECs, and MPs with SCF expression could be a new treatment target to control the development of human chronic periapical disease.

\section{Conflicts of interest}

The authors declare no conflict of interest.

\section{ACKNOWLEDGMENTS}

Research supported by the Science and Technology Planning Project of Guangdong Province, China (\#2013B021800043; \#2014A020212212).

\section{REFERENCES}

Batista AC, Rodini CO and Lara VS (2005). Quantification of mast cells in different stages of human periodontal disease. Oral Dis. 11: 249-254. http://dx.doi.org/10.1111/j.1601-0825.2005.01113.x

Chang J, Zhang C, Tani-Ishii N, Shi S, et al. (2005). NF-kappaB activation in human dental pulp stem cells by TNF and LPS. J. Dent. Res. 84: 994-998. http://dx.doi.org/10.1177/154405910508401105

Genetics and Molecular Research 16 (1): gmr16019394 
Choudhary S, Pardo A, Rosinke R, Batra JK, et al. (2016). Targeting c-kit receptor in neuroblastomas and colorectal cancers using stem cell factor (SCF)-based recombinant bacterial toxins. Appl. Microbiol. Biotechnol. 100: 263-277. http://dx.doi.org/10.1007/s00253-015-6978-2

Fan MW and Zhou XD (2012). Operative dentistry and endodontics. Fourth edition. People's Medical Publishing House, Beijing, 220-221.

Fang X, Han MZ, Zhang M, Jin SZ, et al. (2012). Effects of stem cell factor (SCF) and granulocyte colony stimulating factor (G-CSF) on the transplantation of bone marrow mononuclear cells (BMMCs) for the treatment of acute liver failure. Chin. J. Gastroenterol. Hepatol. 21: 1037-1042.

Gagari E, Rand MK, Tayari L, Vastardis H, et al. (2006). Expression of stem cell factor and its receptor, c-kit, in human oral mesenchymal cells. Eur. J. Oral Sci. 114: 409-415. http://dx.doi.org/10.1111/j.1600-0722.2006.00388.x

Hama S, Takeichi O, Fujisaki K, Tanabe N, et al. (2008). Nitric oxide attenuates vascular endothelial cadherin-mediated vascular integrity in human chronic inflammation. Clin. Exp. Immunol. 154: 384-390. http://dx.doi.org/10.1111/ j.1365-2249.2008.03789.x

Jakovljevic A, Knezevic A, Karalic D, Soldatovic I, et al. (2015). Pro-inflammatory cytokine levels in human apical periodontitis: Correlation with clinical and histological findings. Aust. Endod. J. 41: 72-77. http://dx.doi.org/10.1111/ aej. 12072

Kalra N, Pradeep AR, Priyanka N and Kumari M (2013). Association of stem cell factor and high-sensitivity C reactive protein concentrations in crevicular fluid and serum in patients with chronic periodontitis with and without type 2 diabetes. J. Oral Sci. 55: 57-62. http://dx.doi.org/10.2334/josnusd.55.57

Kim JY, Choi JS, Song SH, Im JE, et al. (2014). Stem cell factor is a potent endothelial permeability factor. Arterioscler. Thromb. Vasc. Biol. 34: 1459-1467. http://dx.doi.org/10.1161/ATVBAHA.114.303575

Lennartsson J and Rönnstrand L (2012). Stem cell factor receptor/c-Kit: from basic science to clinical implications. Physiol. Rev. 92: 1619-1649. http://dx.doi.org/10.1152/physrev.00046.2011

Liu SB and Liu YY (2013). The expression of in induced rat periapical lesion. J. Oral Sci. Res. 29: 1002-1004.

Nair PN (2004). Pathogenesis of apical periodontitis and the causes of endodontic failures. Crit. Rev. Oral Biol. Med. 15: 348-381. http://dx.doi.org/10.1177/154411130401500604

Pradier A, Tabone-Eglinger S, Huber V, Bosshard C, et al. (2014). Peripheral blood CD56(bright) NK cells respond to stem cell factor and adhere to its membrane-bound form after upregulation of c-kit. Eur. J. Immunol. 44: 511-520. http://dx.doi.org/10.1002/eji.201343868

Sipert CR, Morandini AC, Dionísio TJ, Machado MA, et al. (2014). In vitro regulation of CCL3 and CXCL12 by bacterial by-products is dependent on site of origin of human oral fibroblasts. J. Endod. 40: 95-100. http://dx.doi.org/10.1016/j. joen.2013.09.031

Solanki P, Aminoshariae A, Jin G, Montagnese TA, et al. (2013). The effect of docosahexaenoic acid (DHA) on expression of IL-1B, IL-6, IL-8, and TNF- $\alpha$ in normal and lipopolysaccharide (LPS)-stimulated macrophages. Quintessence Int. 44: 393.

Takeichi O, Hama S, Iwata K and Ito K (2008). Confocal immunolocalization of VE-cadherin- and CXC chemokineexpressing endothelial cells in periapical granulomas. Int. Endod. J. 41: 401-407. http://dx.doi.org/10.1111/j.13652591.2007.01369.x

Velickovic M, Pejnovic N, Petrovic R, Mitrovic S, et al. (2016). Expression of interleukin-33 and its receptor ST2 in periapical granulomas and radicular cysts. J. Oral Pathol. Med. 45: 70-76. http://dx.doi.org/10.1111/jop.12312

Genetics and Molecular Research 16 (1): gmr16019394 